\title{
Heavy Metal Concentration from Biologically Important Edible Species of Bivalves (Perna viridis and Modiolus metcalfei) from Vellar Estuary, South East Coast of India
}

\author{
Ponnusamy $\mathbf{K}^{1,2 *}$, Sivaperumal $\mathbf{P}^{1}$, Suresh $\mathbf{M}^{2}$, Arularasan $\mathbf{S}^{2}$, Munilkumar $\mathbf{S}^{1}$ and Pal AK \\ ${ }^{1}$ Central Institute of Fisheries Education, ICAR-Deemed University, Off Yari Road, Versova, Mumbai-400 061, India \\ ${ }^{2}$ CAS in Marine Biology, Faculty of Marine Sciences, Annamalai University, Parangipettai- 608 502, India
}

\begin{abstract}
Commonly mollusks are filter feeding in habits so while feeding from the mud the unwanted chemicals and metals are accumulate in the organs like gills, foot and mantle. These edible bivalves can better be used for biomonitoring in case of the food safety at regularly used by the local fisherman community. So it is very important necessity to study about edible mollusks and with the aim of the present study is carried. Assessment of heavy metal such as $\mathrm{Cd}, \mathrm{Cr}$, $\mathrm{Cu}, \mathrm{Pb}$ and $\mathrm{Zn}$ accumulation of seven different body parts viz, Foot, Mantle, Gonad, Adductor muscle, Byssal thread, Gills and shell from two different edible bivalve species of Perna viridis and Modiolus metcalfei were carried briefly. Among all the metals, $\mathrm{Zn}$ was higher and $\mathrm{Cd}$ was lower concentration were observed from two different bivalve and their values varied with respect to different body parts. The accumulation of these five heavy metals ranged as $\mathrm{Cd}$ $(0.022-0.091 \mu \mathrm{g} / \mathrm{g}), \mathrm{Cr}(0.147-0.447 \mu \mathrm{g} / \mathrm{g}) \mathrm{Cu}(0.126-0.356 \mu \mathrm{g} / \mathrm{g}), \mathrm{Pb}(0.145-1.57 \mu \mathrm{g} / \mathrm{g})$ and $\mathrm{Zn}(0.964-8.607 \mu \mathrm{g} / \mathrm{g})$ for P.viridis and $M$. metcalfei ranged as $\mathrm{Cd}(0.013-0.095 \mu \mathrm{g} / \mathrm{g}), \mathrm{Cr}(0.092-0.495 \mu \mathrm{g} / \mathrm{g}) \mathrm{Cu}(0.063-0.367 \mu \mathrm{g} / \mathrm{g}), \mathrm{Pb}$ $(0.528-1.263 \mu \mathrm{g} / \mathrm{g})$ and $\mathrm{Zn}(2.172-11.113 \mu \mathrm{g} / \mathrm{g})$. Cluster analysis (Bray-Curtis Similarity) was used for making the similarity percentage between different body parts of edible bivalves and comparison also done with sediment metal concentration. In general, all heavy metals are less than the permissible level according to WHO/EPA except $\mathrm{Cr}$ and $\mathrm{Pb}$ from both bivalves.
\end{abstract}

Keywords: Heavy metals; Estuary; Sediment; Perna viridis; Modiolus metcalfei

\section{Introduction}

Heavy metals are persistent pollutants in aquatic ecosystems. The trace metal occurs in all compartments of the marine environment and has a tendency to accumulate in organisms from different tropic levels of marine food webs. The accumulation of trace metals in aquatic organisms can pose a long-term burden on biogeochemical cycling in the ecosphere. Bioaccumulation becomes an environmental problem when chemicals accumulated are toxic. Toxicity may occur along the food chain when the contaminated species or a substance is consumed [1]. An unaltered chemical like copper element can be eliminated rapidly residues will not accumulate and tissue less likely damaged [2]. Once trace metals enter the food chain, they may accumulate to dangerous levels and be harmful to human health [3]. Marine molluscs such as oysters, mussels, cockle and clams have been widely employed as biomonitors for heavy metals pollution due to their ability to accumulate metals without harming themselves. The reliable use of marine molluscs as indicator organisms for metal contamination requires an understanding of how environmental parameters effect metal accumulation. Particularly bivalve molluscs have been considered as a potential biomonitor for metallic contamination in marine ecosystems [4]. They are sedentary and sessile filter-feeders, having a wide geographical distribution. Because of their abundance in coastal water and their ability to accumulate several classes of pollutants, they have been chosen as a suitable organism for mussel watch monitoring programs [5]. Marine organisms are characterized by a greater spatial ability to accumulate some metals when compared with bottom sediments [6]. Filter feeding bivalves capable to accumulate heavy metals in their tissues and numerous studies were attributed. Mussels can accumulate Cd in their tissues at levels up to 100,000 times higher than the level observed in the water in which they live [7].

The wide use of shellfish reflects not only the high capacity of these organisms to bioaccumulation of organic and inorganic contaminants and their widespread distribution, but also their importance, because shellfish represent an important source of protein for coastal communities. It has been predictable, for instance, that over $90 \%$ of human health exposure to several contaminants occurs through diet primarily seafood and meat $[8,9]$. The use of bivalves as biomonitors of heavy metal pollution has been widely reported. This is due to their characteristics from ecological and biological points of view which are advantageous for biomonitoring. Perna viridis and Modiolus metcalfei are usually found in the tropical intertidal area including mangrove trees and estuarine mudflats. Although their abundance and distribution are usually found in Vellar estuary, Southeast coast of India, Tamil Nadu, it's prospective as a biomonitor has not been reported. Hence the present study was estimate the heavy metal concentrations such as $\mathrm{Cd}, \mathrm{Cr}, \mathrm{Cu}$, $\mathrm{Pb}$ and $\mathrm{Zn}$ in different tissue part of Green mussel (Perna viridis) and Horse mussel (Modiolus metcalfei) collected from Vellar Estuary.

\section{Materials and Methods}

\section{Study area}

The vellar estuary lies between (Lat $110^{\circ} 30^{`} \mathrm{~N}$; Long. $79^{\circ} 46^{`} \mathrm{E}$ ), the southeast coast of India, which originates from the Shervarayan

*Corresponding author: Ponnusamy K, Central Institute of Fisheries Education ICAR- Deemed University, Off Yari Road, Versova, Mumbai, India, Tel: 91 9894500278; E-mail: marine.ponnusamy@gmail.com

Received July 15, 2014; Accepted August 06, 2014; Published August 14, 2014

Citation: Ponnusamy K, Sivaperumal P, Suresh M, Arularasan S, Munilkumar S et al. (2014) Heavy Metal Concentration from Biologically Important Edible Species of Bivalves (Perna viridis and Modiolus metcalfei) from Vellar Estuary, South East Coast of India. J Aquac Res Development 5: 258. doi:10.4172/2155-9546.1000258

Copyright: ( 2014 Ponnusamy K, et al. This is an open-access article distributed under the terms of the Creative Commons Attribution License, which permits unrestricted use, distribution, and reproduction in any medium, provided the original author and source are credited. 
Citation: Ponnusamy K, Sivaperumal P, Suresh M, Arularasan S, Munilkumar S, et al. (2014) Heavy Metal Concentration from Biologically Important Edible Species of Bivalves (Perna viridis and Modiolus metcalfei) from Vellar Estuary, South East Coast of India. J Aquac Res Development 5: 258. doi:10.4172/2155-9546.1000258

hills of Salam district in Tamilnadu, India. After traversing distance of about $480 \mathrm{Km}$, it forms an extensive estuarine system at parangipettai, before it joins with the Bay of Bengal. It has fringed with variety of mangrove plants, mud flat shrubs which serve as significant breeding ground for number of marine and brackish water organisms. It is one of the fertile estuaries in Tamil Nadu. Basically estuaries serve as both pollution sources for the coastal sea and marginal filter to the polluted runoff from the river drainage basin. Particularly Vellar estuary highly influenced by human inhabitation, mechanized boat withstand on estuary, agriculture and aquaculture activities, which could possibly introduce consideration level of contaminants into the water body as well as mussels. Due to this reason accumulation of metals such as $\mathrm{Cd}$, $\mathrm{Cr}, \mathrm{Cu}, \mathrm{Pb}$ and $\mathrm{Zn}$ were estimated in sediment and different body parts of the P. viridis and M. metcalfei were as Foot, Mantle, Gonad, Adductor Mussel, Shell, Byssal Thread and Gills.

\section{Sample collection and preparation}

Sediment samples were collected using a pre cleaned and acid washed PVC corer and immediately kept in pre cleaned and acid washed polythene bags, which were sealed and kept in ice box until further analysis in the laboratory. Sediment samples were washed with metal free double distilled water. The sediment samples were dried in an over at $60^{\circ} \mathrm{C}$ for 5-6 hours. Dried sediment samples were ground in a glass mortar and reduced into fine particles.

A total of 60 green mussels, $P$. virids and 100 of yellow banded horse mussel, $M$. metcalfei were collected randomly by hand picking during low tide from Vellar estuary. The mussels were identified based sufficient taxonomic tools [10]. Collected mussels were cleaned to remove adhering on mussels with the fresh water and soft tissues were removed from the shells with a plastic knife. Different body parts of the each species were dissected and pooled together with respective body parts for mass quantification to analyze the heavy metal concentrations. Further, the different body parts dried at $60^{\circ} \mathrm{C}$ and ground well to obtain fine powder before analysis.

\section{Determination of metal concentration}

To estimate the metal content $(\mathrm{Cd}, \mathrm{Cr}, \mathrm{Cu}, \mathrm{Pb}$ and $\mathrm{Zn})$ samples were digested $(1 \mathrm{~g})$ with Conc. $\mathrm{HNO}_{3}$ and Conc. $\mathrm{HClO}_{4}$ (4:1). The samples were subjected to complete dryness by placing on a hot plate. The ash consequently obtained was made up to $20 \mathrm{ml}$ solution using ultrapure water from Milli- $Q^{\infty}$ water system with $20 \%$ nitric acid. The mixture was filtered using Whatman filter paper $(11 \mu \mathrm{m})$ and then the metal concentrations were determined using Inductively Coupled Plasma Optical Emission Spectrometer (ICP-OES) (Software- WinLab 32; Perkin Elmer, Optima 2IOODV). The different metals were analyzed by ICP-OES using followed wavelength such as $\mathrm{Cd}$ (228.802), $\mathrm{Cu}$ (324.752), Pb (220.353), Zn (213.857) and Cr (267.716).

\section{Statistical analysis}

All analysis was performed in triplicate and mean, SD were done through SPSS (v16) software and Bray Curtis similarity index was carried out by Primer 6 (v6).

\section{Results}

In the present study, $\mathrm{Cd}, \mathrm{Cr}, \mathrm{Cu}, \mathrm{Pb}$ and $\mathrm{Zn}$ concentrations were determined in sediment and dry weight of different body parts (Foot, Mantle, Gonad, Adductor Mussel, Shell, Byssal Thread and Gills) of two edible bivalves (M. metcalfei and P. viridis). The metal concentration and the corresponding mean standard deviations all the samples from both bivalves are shown in Tables 1 and 2. Concentration of the heavy metals significantly varied in the different body parts of samples collected from the two bivalves. In M. metcalfei, the concentration of Cd ranged from $0.013 \pm 0.0011$ (BT-Byssal Thread) to $0.095 \pm 0.0012$ (FT-Foot) $\mu \mathrm{g} / \mathrm{g}$ and Cr $0.092 \pm 0.0011$ (SL-Shell) to $0.495 \pm 0.002$ (BT-Byssal Thread) $\mu \mathrm{g} / \mathrm{g}$, and $\mathrm{Cu} 0.063 \pm 0.0011$ (BT-Byssal Thread) to $0.367 \pm 0.0043$ (FTFoot) $\mu \mathrm{g} / \mathrm{g}$, and $\mathrm{Pb} 0.164 \pm 0.002$ (BT- Byssal Thread) to $1.263 \pm 0.002$ (GL-Gill) $\mu \mathrm{g} / \mathrm{g}$, and Zn $2.172 \pm 0.0011$ (BT-Byssal Thread) to $11.113 \pm$ 0.023 (AR-Aductor) $\mu \mathrm{g} / \mathrm{g}$ (Table 1). In P. viridis, the concentration of Cd ranged from $0.022 \pm 0.0023$ (GL-Gill) to $0.091 \pm 0.0012$ (FT-Foot) $\mu \mathrm{g} / \mathrm{g}$, and Cr $0.147 \pm 0.0012$ (FT-Foot) to $0.447 \pm 0.012$ (GD-Gonad) $\mu \mathrm{g} / \mathrm{g}$, and $\mathrm{Cu} 0.126 \pm 0.071$ (ML-Mantle) to $0.356 \pm 0.002$ (SL-Shell) $\mu \mathrm{g} / \mathrm{g}$, and $\mathrm{Pb} 0.145 \pm 0.0012$ (GL-Gill) to $1.57 \pm 0.0012$ (GD-Gonad) $\mu \mathrm{g} / \mathrm{g}$ and $\mathrm{Zn} 0.964 \pm 0.002$ (SL-Shell) to $8.607 \pm 0.004$ (FT-Foot) $\mu \mathrm{g} / \mathrm{g}$ (Table 2). In M. metcalfei, accumulation of $\mathrm{Zn}$ was found to be higher followed by $\mathrm{Pb}, \mathrm{Cu}, \mathrm{Cr}$ and $\mathrm{Cd}$ and $P$. viridis also higher concentration present in $\mathrm{Zn}$ and followed by $\mathrm{Pb}, \mathrm{Cr}, \mathrm{Cu}$ and $\mathrm{Cd}$. All metals were commonly found in all the body parts of edible bivalves, but accumulation rate different from body parts as well as mussels. Depending upon the overall average mean value of each metal, the metal accumulation was in the order of different body parts of M. metcalfei and P.viridis presented in

\begin{tabular}{|c|c|c|c|c|c|c|c|c|c|}
\hline Metals & Gonad & Mantle & Aductor & Shell & Byssal Thread & Gill & Foot & Sediment & $\begin{array}{l}\text { WHO/EPA } \\
\text { Standard }\end{array}$ \\
\hline $\mathrm{Cd}$ & $0.042 \pm 0.0012$ & $0.044 \pm 0.002$ & $0.015 \pm 0.0023$ & $0.014 \pm 0.0011$ & $0.013 \pm 0.0011$ & $0.023 \pm 0.0011$ & $0.095 \pm 0.0012$ & $0.135 \pm 0.001$ & $0.0-0.2$ \\
\hline $\mathrm{Cr}$ & $0.383 \pm 0.001$ & $0.097 \pm 0.002$ & $0.124 \pm 0.002$ & $0.092 \pm 0.0011$ & $0.495 \pm 0.002$ & $0.142 \pm 0.0012$ & $0.123 \pm 0.0012$ & $0.521 \pm 0.0012$ & $0.1-0.15$ \\
\hline $\mathrm{Cu}$ & $0.295 \pm 0.001$ & $0.324 \pm 0.002$ & $0.073 \pm 0.002$ & $0.125 \pm 0.002$ & $0.063 \pm 0.0011$ & $0.227 \pm 0.0012$ & $0.367 \pm 0.0043$ & $0.389 \pm 0.0012$ & $0-10$ \\
\hline $\mathrm{Pb}$ & $0.327 \pm 0.0012$ & $0.194 \pm 0.0012$ & $0.195 \pm 0.002$ & $0.175 \pm 0.0023$ & $0.164 \pm 0.002$ & $1.263 \pm 0.002$ & $0.528 \pm 0.0012$ & $2.057 \pm 0.02$ & $0-1.5$ \\
\hline $\mathrm{Zn}$ & $2.374 \pm 0.002$ & $5.795 \pm 0.002$ & $11.113 \pm 0.023$ & $3.626 \pm 0.002$ & $2.172 \pm 0.0011$ & $4.324 \pm 0.0023$ & $5.343 \pm 0.016$ & $9.486 \pm 0.003$ & $58-150$ \\
\hline
\end{tabular}

Table 1: Heavy metal concentration in different body parts from $M$. metcalfei $(\mu \mathrm{g} / \mathrm{g})$.

\begin{tabular}{|c|c|c|c|c|c|c|c|c|c|}
\hline Metals & Gonad & Mantle & Aductor & Shell & Byssal Thread & Gill & Foot & Sediment & $\begin{array}{l}\text { WHO/EPA } \\
\text { Standard }\end{array}$ \\
\hline $\mathrm{Cd}$ & $0.057 \pm 0.013$ & $0.035 \pm 0.015$ & $0.025 \pm 0.002$ & $0.038 \pm 0.0012$ & $0.071 \pm 0.002$ & $0.022 \pm 0.0023$ & $0.091 \pm 0.0012$ & $0.135 \pm 0.001$ & $0.0-0.2$ \\
\hline $\mathrm{Cr}$ & $0.447 \pm 0.012$ & $0.234 \pm 0.123$ & $0.269 \pm 0.0012$ & $0.184 \pm 0.002$ & $0.334 \pm 0.015$ & $0.196 \pm 0.002$ & $0.147 \pm 0.0012$ & $0.521 \pm 0.0012$ & $0.1-0.15$ \\
\hline $\mathrm{Cu}$ & $0.314 \pm 0.0012$ & $0.126 \pm 0.071$ & $0.187 \pm 0.0012$ & $0.356 \pm 0.002$ & $0.281 \pm 0.002$ & $0.153 \pm 0.0023$ & $0.239 \pm 0.0023$ & $0.389 \pm 0.0012$ & $0-10$ \\
\hline $\mathrm{Pb}$ & $1.57 \pm 0.0012$ & $0.736 \pm 0.002$ & $0.362 \pm 0.0012$ & $0.355 \pm 0.002$ & $0.199 \pm 0.0012$ & $0.145 \pm 0.0012$ & $0.209 \pm 0.0034$ & $2.057 \pm 0.02$ & $0-1.5$ \\
\hline $\mathrm{Zn}$ & $2.57 \pm 0.002$ & $1.164 \pm 0.0012$ & $1.514 \pm 0.0012$ & $0.964 \pm 0.002$ & $2.246 \pm 0.0012$ & $4.445 \pm 0.0023$ & $8.607 \pm 0.004$ & $9.486 \pm 0.003$ & $58-150$ \\
\hline
\end{tabular}

Table 2: Heavy metal concentration in different body parts from $P$. viridis $(\mu \mathrm{g} / \mathrm{g})$. 
Citation: Ponnusamy K, Sivaperumal P, Suresh M, Arularasan S, Munilkumar S, et al. (2014) Heavy Metal Concentration from Biologically Important Edible Species of Bivalves (Perna viridis and Modiolus metcalfei) from Vellar Estuary, South East Coast of India. J Aquac Res Development 5: 258. doi:10.4172/2155-9546.1000258

Page 3 of 5

\begin{tabular}{|c|c|c|}
\hline $\begin{array}{c}\text { Heavy } \\
\text { Metal }\end{array}$ & M. metcalfei & P.viridis \\
\hline $\mathrm{Cd}$ & $\mathrm{SM}>\mathrm{FT}>\mathrm{ML}>\mathrm{GD}>\mathrm{GL}>\mathrm{AR}>\mathrm{SL}>\mathrm{BT}$ & $\mathrm{SM}>\mathrm{FT}>\mathrm{BT}>\mathrm{GD}>\mathrm{SL}>\mathrm{ML}>\mathrm{AR}>\mathrm{GL}$ \\
\hline $\mathrm{Cr}$ & $\mathrm{SM}>\mathrm{BT}>\mathrm{GD}>\mathrm{GL}>\mathrm{AR}>\mathrm{FT}>\mathrm{ML}>\mathrm{SL}$ & $\mathrm{SM}>\mathrm{GD}>\mathrm{BT}>\mathrm{AR}>\mathrm{ML}>\mathrm{GL}>\mathrm{SL}>\mathrm{FT}$ \\
\hline $\mathrm{Cu}$ & $\mathrm{SM}>\mathrm{FT}>\mathrm{ML}>\mathrm{GD}>\mathrm{GL}>\mathrm{SL}>\mathrm{AR}>\mathrm{BT}$ & $\mathrm{SM}>\mathrm{SL}>\mathrm{GD}>\mathrm{BT}>\mathrm{FT}>\mathrm{AR}>\mathrm{GL}>\mathrm{ML}$ \\
\hline $\mathrm{Pb}$ & $\mathrm{AM}>\mathrm{GL}>\mathrm{FT}>\mathrm{GD}>\mathrm{AR}>\mathrm{ML}>\mathrm{SL}>\mathrm{BT}$ & $\mathrm{SM}>\mathrm{GD}>\mathrm{ML}>\mathrm{AR}>\mathrm{SL}>\mathrm{FT}>\mathrm{BT}>\mathrm{GL}$ \\
\hline $\mathrm{Zn}$ & $\mathrm{AR}>\mathrm{SM}>\mathrm{ML}>\mathrm{FT}>\mathrm{GL}>\mathrm{SL}>\mathrm{GD}>\mathrm{BT}$ & $\mathrm{SM}>\mathrm{FT}>\mathrm{GL}>\mathrm{GD}>\mathrm{BT}>\mathrm{AR}>\mathrm{ML}>\mathrm{SL}$ \\
\hline
\end{tabular}

FT-Foot; ML-Mantle; GD-Gonad; GL-Gill; AR-Aductor; SL-Shell; BT-Byssal Thread; SM-Sediment

Table 3: Order of the metal concentration recorded in different body parts of edible mussels from Vellar Estuary.

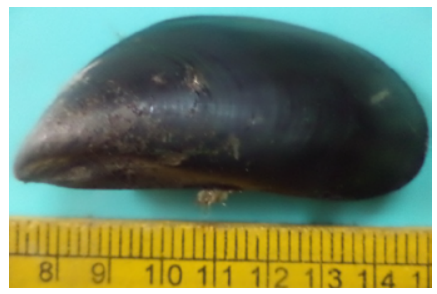

(A)

Figure 1: Study animal: A- Perna viridis $(7.8 \mathrm{~cm}$ length) and B- Modiolus metcalfei $(7.6 \mathrm{~cm}$ length).

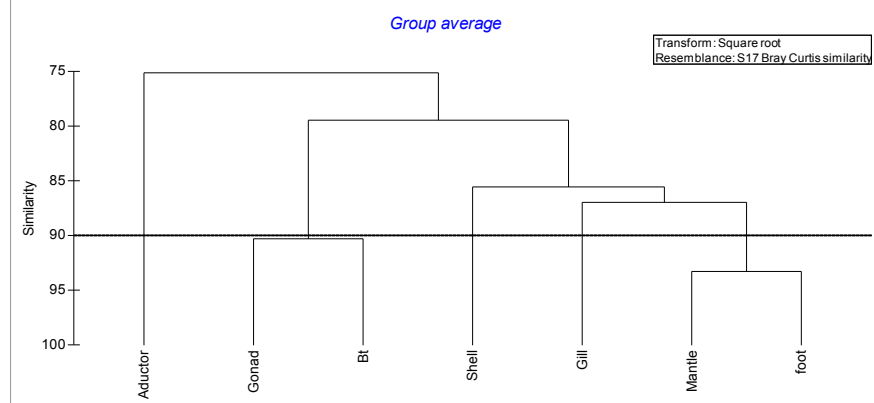

Figure 2: Bray Curtis similarity index versus different body parts of $M$. metcalfei. (Bt-Byssal Thread).

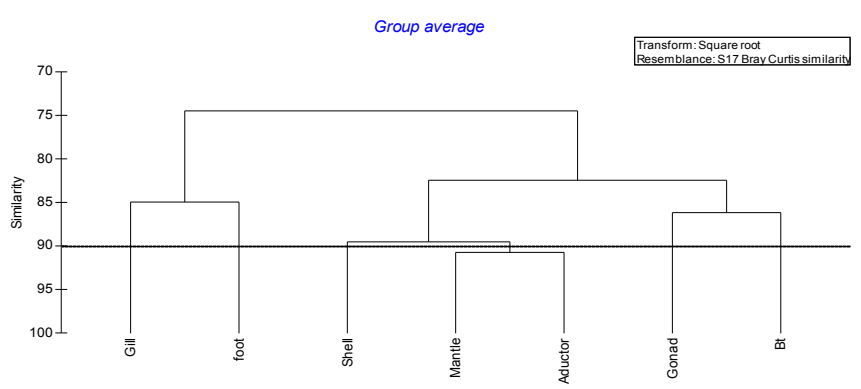

Figure 3: Bray Curtis similarity index versus different body parts of $P$. viridis. (Bt-Byssal Thread).

Table 3. All the metals are permissible level according to WHO/EPA except $\mathrm{Cr}$ and $\mathrm{Pb}$ from both bivalves. Sediment metal concentrations, comparatively higher than the both bivalves different body parts except Aductor (AT) of $M$. metcalfei. Moreover, there are the comprehensible relationships between concentrations of heavy metals in the mussels and sediment (Figure 1).

Dendrograms (Figures 2 and 3) are drawn to identifying the similarity percentage of heavy metal accumulation at different body parts using group linkage clustering technique (Bray Curtis Similarity coefficient of similarity). Mantle (MT) and Foot (FT) parts were at the highest level of (93.25\%) of similarity at M. metcalfei followed by Gonad (GD) and Byssal Thread (BT) were successfully grouped by the next level of similarity (90.26\%). In $P$. viridis, highest level of similarity present between (90.07\%) Mantle (ML) and Aductor (AT).

\section{Discussion}

Sediments are one of the major sinks of trace metals in the aquatic environment and may be good indicators of long and medium term metal loads. Likewise, molluscan shell and tissue are also good indicator of metal pollution as they are sessile and sedentary and they reflect the heavy metal concentration of that particular area [11]. As expected, heavy metal concentrations in sediments greatly exceeded those in the surrounding water. In aquatic environments, heavy metals discharged from industrial or sewage effluents or from atmospheric deposition may be rapidly removed from the water column and transported to the bottom sediments [12]. The availability of metals in sediment provides an opportunity for aquatic animals to biomagnify these metals and later remobilized them through the food chain. In the present study, P.viridis and M. metcalfei from Vellar estuary was studied in different body part of the tissue for the level of accumulation of various metals apart from comparing the concentration with that of the sediment. Previously [13] reported that the level of heavy metal concentration from marine mollusc and sediment were reported. $\mathrm{Cr}$ in sediment was ranging between $7.10 \mu \mathrm{g} / \mathrm{g}$ and $31.44 \mu \mathrm{g} / \mathrm{g}$ and $\mathrm{Cu}$ concentration ranged from $11.28 \mu \mathrm{g} / \mathrm{g}$ to $37.24 \mu \mathrm{g} / \mathrm{g}$ and $\mathrm{Zn}$ concentration (36.14 to 56.14 $\mu \mathrm{g} / \mathrm{g}$ ) the sediment of Vellar estuary. Likewise copper in sediments collected from the Lukang culture area of central Taiwan and also evaluates the relationship by purble clams (Hiatula diphos) and venus clams (Gomphina aguilatera) [14].

Compare to previous study we observed less concentration of $\mathrm{Cr}$, $\mathrm{Cu}$ and $\mathrm{Zn}$ in the sediment samples due to the continuous runoff water in the estuarine environment. But sediment metal concentrations, comparatively higher than the both bivalves different body parts except Aductor (AT) of M. metcalfei. Moreover, there are the comprehensible relationships between concentrations of heavy metals in the mussels and sediment. All the metals are permissible level according to $\mathrm{WHO} /$ EPA except $\mathrm{Cr}$ and $\mathrm{Pb}$ from sediment.

The use of molluscan shells as sentinels for metal pollution monitoring in marine waters has several advantages over that of the soft tissues. The shells are easy to store and handle and appear to be sensitive to environmental heavy metals over the long term. Since shell growth occurs incrementally they can provide a signal over a discrete time period, unlike the tissues which are strong accumulator of metals and integrate the chemical contamination signal over the life of the organism. Refinement of techniques for determining element using bivalves is important if global monitoring is to become a reality [15]. Another important observation in the present study, we estimated in different body parts of the edible bivalves such as Foot, Mantle, Gonad, Adductor Mussel, Shell, Byssal Thread and Gills. Previously same kinds of finding as bioaccumulation of some heavy metals $(\mathrm{Cd}, \mathrm{Fe}, \mathrm{Zn}$ and $\mathrm{Cu}$ ) were done from fresh parts of two bivalves (Pincta daradiata and Brachidonets pharaonsis) from Akkuya Bay [16]. Similarly [17] reported that bioaccumulation of heavy metals such as magnesium, iorn, zinc and copper concentration in different body parts and shell of C. melo from Cuddalore coast. Previously [18] reported that, level of accumulation of heavy metals such as mercury, cadmium, lead, zinc, copper and arsenic in soft tissues of 15 species of benthic invertebrates 
Citation: Ponnusamy K, Sivaperumal P, Suresh M, Arularasan S, Munilkumar S, et al. (2014) Heavy Metal Concentration from Biologically Important Edible Species of Bivalves (Perna viridis and Modiolus metcalfei) from Vellar Estuary, South East Coast of India. J Aquac Res Development 5: 258. doi:10.4172/2155-9546.1000258

Page 4 of 5

from Zhejiang coastal waters, East china. The concentration of iron in the different soft tissues and byssus and also studied the potential role of the byssus as an excretion route for iorn in P. viridis [19]. In the present observation of heavy metals concentration also considerably varied in the different body parts of two edible bivalves. The concentration of Cd was minimum $0.013 \pm 0.0011 \mu \mathrm{g} / \mathrm{g}$ (BT-Byssal Thread) and $\mathrm{Cr}$ had maximum $(0.495 \pm 0.002 \mu \mathrm{g} / \mathrm{g})$ ranges observed from $M$. metcalfei. In case of $\mathrm{Cu}, \mathrm{Pb}$ and $\mathrm{Zn}$ was minimum (Byssal Thread (BT)) ranges compare to other body parts.

$\mathrm{Cu}$ in the different soft tissues of the bivalve might be due to various mechanisms which included homoeostatic processes in the body in response to varying metabolic demands and entrapment of $\mathrm{Cu}$ under certain conditions by additional mucilage production/extrusion by animal [20]. Cadmium is widely distributed at low level in the environment and most foods have an inherently low level of $\mathrm{Cd}$ which has been shown to bind to the protein and accumulate significantly in higher level [21]. In present investigation, $P$. viridis metal concentration of Cd ranges minimum $(0.022 \pm 0.0023 \mu \mathrm{g} / \mathrm{g})$ Gill part $(\mathrm{GL})$ and maximum $0.091 \pm 0.0012 \mu \mathrm{g} / \mathrm{g}$ recorded at Foot $(\mathrm{FT})$ part [22] Reported that Cd level is almost 10 times higher in shell fishes than in finfishes. This could also be due to fertilizer application in nearby area are transported to the estuaries by leaching and erosion as agriculture is also an important activity of the village folks besides fishing. According to $\mathrm{Li}$ [23], bivalves do not regulate Cd usually accumulate this element. Hence, green mussel might be able to regulate $\mathrm{Cd}$ in their body. Zinc is an essential trace element for all living organisms. Previously Vellar eastuarine gastropod $\mathrm{Cd}$ concentration was found fluctuating from 0.48 to $2.44 \mu \mathrm{g} / \mathrm{g}$ in the body tissues of Nerita crepidularia [13]. In the earlier, Cd concentration was found to be $(6.88 \pm 1.02) \mu \mathrm{g} / \mathrm{g}$ in Nerita albicilla from Taiwan coast [24], 1.78-2.87 $\mu \mathrm{g} / \mathrm{g}$ in Nerita albicilla from marine environment, Hong Kong [25] and $2.83 \mu \mathrm{g} / \mathrm{g}$ in $N$. lineata from Peninsular, Malaysia [26]. Comparatively present study, Cd concentration were observed form both edible bivalves concentration was low. Similarly Zinc concentration of foot part in M. metcalfei ( 5.343 $\pm 0.016)$ and $P$. viridis $(8.607 \pm 0.004)$ was lower when comparing the results for $63.90-81.75 \mu \mathrm{g} / \mathrm{g}$ in Sunderban mangroves [27] in Erita articulata; $150-130 \mu \mathrm{g} / \mathrm{g}$ in Taiwan coastal waters [24] in Nerita albicilla and 31-680 $\mu \mathrm{g} / \mathrm{g}$ in S. Khatib, Singapore [28] in N. lineata.

\section{Conclusion}

In the present study, the present status of heavy metal concentration from most edible bivalves was examined. Both edible bivalve may be used as an indicator species of heavy metal pollution and therefore can be used as sentinel organism to monitor pollution in the estuarine environment due to the following reasons. The tissues of different body parts were polluted by $\mathrm{Zn}$ and $\mathrm{Cd}$ compare to other heavy metals $(\mathrm{Pb}, \mathrm{Cr}$ and $\mathrm{Cu})$ and $\mathrm{Cr}$ and $\mathrm{Pb}$ beyond the limit of permissible level according to WHO/EPA from both bivalves as well as sediment also, it may be used as a biomonitor of certain heavy metals in Vellar estuary environment.

\section{Acknowledgement}

Authors are thankful to authorities of CAS in Marine Biology, Annamalai University and Board of Research in Nuclear Sciences (BRNS), Mumbai-400085.

\section{References}

1. Heng LY, Mokhtar MB, Rusin S (2004) The bioaccumulation of Trace Essential Metals by the freshwater Snail Turritella $s p$. Found in the Rivers of Borneo East Malaysia. J Bio Sci 4: 441-444.

2. Subathra S, Karuppasamy RAE (2008) Bioaccumulation and Depuration Pattern of Copper in Different Tissues of Mystus vittatus, Related to Various Size Groups. Arch Environ Contam Toxicol 54: 236-244.
3. Manahan SE (2000) Environmental Chemistry. Lewis Publishers, Boca Raton Florida, USA.

4. Jung K, Zauke GP (2008) Bioaccumulation of trace metals in the brown shrimp Crangon crangon (Linnaeus, 1758) from the German Wadden Sea. Aquat Toxicol 88: 243-249.

5. Goldberg ED (1975) The mussel watch-A first step in global marine monitoring Mar Poll Bull 6: 111-132.

6. Kaladharan P, Prema D, Valsala KK, Leelabhai KS, Rajagopalan M (2005) Trends in heavy metal concentrations in sediment, fin fishes and shellfishes in inshore waters of Cochin, southwest coast of India. J Mar Biol Ass 47: 1-7.

7. Avelar WEP, Mantelatto FLM, Tomazelli AC, Silva DL, Shuhama T, et al., (2000) The marine mussel Perna perna as an indicator of contamination by heavy metals in the Ubatuba bay, SaoPaula, Brazil. Water Air Soil Poll 118: 65-72.

8. Kim M, Wolt JD (2011) Probabilistic risk assessment of dietary cadmium in the South Korean population. Food Aditives \& Contaminents: Part A 28: 62- 70.

9. Smith AG, Gangolli SD (2002) Organochlorine chemicals in seafood: occurrence and health concerns. Food and Chem Toxicol 40: 767-779.

10. Shanmugam A, Rajagopal S, Nazeer RA (1997) A monograph on the common bivalves of Parangipettai coast. Annamalai University, India.

11. Brugmann L (1981) Heavy metals in the Baltic Sea. Mar Pollu Bull 12: 214-218.

12. Fung YS, Lo CK (1992) Heavy metal pollution profiles of dated sediment cores from Hebe haven, Hong Kong. Wat Res 26: 1605-1619.

13. Palpandi C, Kesavan K (2012) Heavy metal monitoring using Nerita crepidulariamangrove mollusc from the Vellar estuary, Southeast coast of India. APJTB 2 S358-S367.

14. Han BC, Jeng WL, Jeng MS, Kao LT, Meng PJ, et al., (1997) Rock-shells (Thais clavigera) as an indicator of $\mathrm{As}, \mathrm{Cu}$ and $\mathrm{Zn}$ contamination on the Putai Coast of the Black-foot Disease area in Taiwan. Arch of Environ Cont Toxicol 32: 456 461

15. Phillips DJH (1980) Quantitative aquatic biological indicators: Their use to monitor trace metal and organo chlorine pollution. Applied Science Publisher, USA.

16. Goksu MZL, Akar M, Evik F, Findik (2005) Bioaccumulation of some heavy metals in two bivalvia species. Turk J Vet Anim Sci 29: 89-93.

17. Shanmugam A, Palpandi C, Kesavan K (2007) Bioaccumulation of Some Trace Metals (Mg, Fe, Zn, Cu) from Begger's Bowl Cymbium melo (Solander, 1786) (A Marine Neogastropod). Research J Environ Sci 1: 191-195.

18. Huang JY, Wu JH (2007) Heavy metal monitoring using bivalved shellfish from Zhejiang coastal waters, East China Sea. Environ Monitoring Assess 129: 315320 .

19. Yap CK, Tan SG (2007) Iron (Fe) Concentrations in the byssus and soft tissues of the green-lipped mussel Perna viridis (L.): Byssus as an excretion route of $\mathrm{Fe}$ and Fe bioavailability in the coastal waters. Ind J Mar Sci 36: 227-234.

20. Pyatt FB, Metcalfe MR, Pyatt AJ (2003) Copper bioaccumulation by the freshwater snail Lymnaea peregra: A toxicological marker of environmental and human health. Environ Toxicol Chem 22: 561-564.

21. FDA (2011) Fish and Fisheries Products Hazards and Controls Guidance Fourth Edition. Centre for Food Safety and Applied Nutrition, US Food and Drug Administration.

22. Ololade IA, Lajide L, Amoo IA, Oladoja NA (2008) Investigation of heavy metals contamination of edible marine seafood. Afr J Pure Appl Chem 2: 121-131.

23. Li Y, Yu Z, Song X, Mu Q (2006) Trace metal concentrations in suspended particles, sediments and clams (Ruditapes philippinarum) from Jiaozhou bay of China. Environ Monitoring Assess 121: 491-501.

24. Hung TC, Meng PJ, Han BC, Chang A, Huang CC (2001) Trace metals in different species of mollusks, water and sediments from Taiwan coastal area Chem 4: 833-841.

25. Blackmore $G$ (2001) Interspecific variation in heavy metal body concentrations in Hong Kong marine invertebrates. Environ Pollut 114: 303-311.

26. Yap CK, Cheng WH (2009) Heavy metal concentration in Nerita lineate: the potential as a biomonitor for heavy metal bioavailability and contamination in the tropical intertidal area. Marine Biodiversity Records 2: e49. 
Citation: Ponnusamy K, Sivaperumal P, Suresh M, Arularasan S, Munilkumar S, et al. (2014) Heavy Metal Concentration from Biologically Important Edible Species of Bivalves (Perna viridis and Modiolus metcalfei) from Vellar Estuary, South East Coast of India. J Aquac Res Development 5: 258. doi:10.4172/2155-9546.1000258

Page 5 of 5

27. Mitra C (1993) Heavy metal concentration in Nerita articulate from Sunderban mangroves. Mar Pollut Bull 21: 307-308.
28. Cuong DT, Bayer S, Wurl O, Subramanian K, Wong KKS, et al., (2005) Heavy metal contamination in mangrove habitats of Singapore. Mar Poll Bull 50: 17321738 